\title{
Biological Risk Assessment: Zika Virus Detection at the Research Institute for Tropical Medicine
}

Plebeian Medina, Catherine Calzado, Rex Centeno, Amado Tandoc III, Socorro Lupisan

Research Institute for Tropical Medicine

\section{ABSTRACT}

Background. Biosafety is the application of containment principles and risk assessment. Risk assessment is an essential component of a biological risk management program. It determines the most appropriate mitigation control measure to minimize the risk of Laboratory Acquired Infections (LAIs). In the laboratory response to an emerging disease-causing pathogen such as Zika virus, the risk for laboratory exposure and infection must be assessed.

Objectives. We have conducted biosafety risk assessment of the Research Institute for Tropical Medicine's (RITM) Virology Laboratory to identify the hazards, characterize the risks, determine laboratory compliance with biosafety standards and the competence of the laboratory personnel involved as part of the institutional preparedness for disease outbreak investigation and surveillance of Zika virus. The information gathered shall guide the selection of appropriate mitigation control measures for the prevention of LAls.

Methodology. We utilized the Biosafety for Microbiological and Biomedical Laboratories (BMBL) 5th Edition guidelines in conducting risk assessment. Risk characterization was performed by determining the likelihood and the consequence of the identified biological risk and plotting it in a diagram using Microsoft Excel. Risk characterization result of ZikV was compared using the risk assessment tool, BioRAM@, developed by Sandia National Laboratory.

Results. The RITM Virology laboratory is generally compliant to the basic biosafety standards. Laboratory staff has established competence and experience in handling specimens for diagnostic test by ELISA and PCR. The risk of infection with ZikV is found to range from very low to low, however, the risk of acquiring other bloodborne pathogens brought by handling serum samples is found to be higher.

Conclusion. We have analyzed the risk of acquiring Zika at the RITM Virology laboratory as part of the Institute's overall preparedness, through biological risk assessment process as described in BMBL 5th Edition. The risk of acquiring ZikV infection while performing diagnostic tests range from very low to low. The risk of acquiring other blood-borne pathogens is higher compared to the risk of infection to the pathogen being assessed. Mitigation control measures against direct contact and percutaneous exposure must be implemented and monitored. This risk assessment strategy will further strengthen RITM laboratory's capacity to respond to infectious disease threats and increase staff confidence in dealing with infectious materials in the laboratory.

Key words: Zika virus, biosafety risk, risk assessment, biosafety, biohazards, likelihood, consequence, BioRAM@

ISSN 0118-3265

Printed in the Philippines.

Copyright (C) 2016 by the PJP.

Received: 6 April 2016.

Accepted: 20 April 2016

Published online first: 27 April 2016.

http://dx.doi.org/10.21141/PJP.2016.004

Corresponding author: Catherine E. Calzado, RMT

E-mail: catherine.calzado@yahoo.com

\section{INTRODUCTION}

Zika virus $(\mathrm{ZikV})$ has emerged as a global public health threat over the last decade, with the accelerated geographic spread of the virus noted during the last 5 years. ${ }^{1}$ The first major outbreak outside Africa occurred in 2007 in the Yap Islands of Micronesia, ${ }^{2}$ another large outbreak in 2013 in French Polynesia, ${ }^{3}$ and Brazil in $2015 .{ }^{4}$ The World Health Organization (WHO) has recently declared Zika virus as a public health emergency of international concern (PHEIC), due to its rapid spread and the increase in Zika-associated newborn microcephaly cases. ${ }^{5}$

In the Philippines, the first recorded case of $\mathrm{ZikV}$ was in Cebu in 2012 and none after that. ${ }^{6}$ Recently, the Department of Health (DOH) reported a case of a traveller from the Philippines being diagnosed of a Zika infection upon her return to the United States.

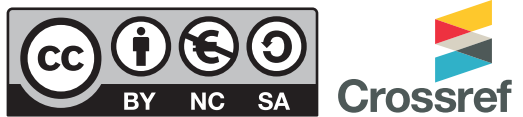


The Research Institute for Tropical Medicine, the research arm of the Department of Health, houses the National Reference Laboratory for Dengue and other Arboviruses. This laboratory is equipped to perform Polymerase Chain Reaction (PCR) testing for suspected ZikV cases in the Philippines. An important component in laboratory-surveillance preparedness is the biological risk assessment of the laboratory to ensure compliance to biosafety standards. It determines the most appropriate containment required to mitigate the risk of Laboratory Acquired Infections (LAIs).

The risk assessment process identifies the hazardous characteristics of an infectious or potentially infectious pathogen or biological agent, the activities that could brace a mean towards unintentional exposure, the likelihood that such exposure could lead to an acquired infection, and its probable consequences. ${ }^{8}$ The information identified by this process provides a clear guide for the selection of appropriate laboratory biological safety levels (practices, safety equipment and physical containment/facilities) in order to minimize the risk of exposure.

\section{METHODOLOGY}

We utilized the Biosafety for Microbiological and Biomedical Laboratories (BMBL) 5th Edition guidelines in conducting biological risk assessment. This process includes identifying the hazard of the agent and the procedure, determining the compliance of the facility with the standards, verifying competence of staff who will be involved in the performance of procedures, and lastly, the review of the process and findings with the biosafety experts of the institution. The consequence of exposure to other blood-borne pathogens, which may be contained in the samples, was described but not detailed in this report.

Risk characterization was performed by determining the likelihood and the consequence and plotting it in a risk matrix diagram using Microsoft Excel. Likelihood is the probability of the occurence of unwanted event, while consequence pertains to its severity. We have assigned values 1, 2, 3, 4 and 5 for the likelihood and consequence. For both likelihood and consequence we have agreed that 1 should be the lowest semiquantitative value, while 5 should be assigned as the highest. We have compared our risk characterization result using the BioRAM $\odot$ risk assessment tool developed by Sandia National Laboratory.

The process, results and the findings for compliance and noncompliance were reviewed and verified by a senior Certified Biosafety Officer of the Institute.

\section{RESULTS}

\section{Identification of the Agent Hazard}

Zika virus or $\mathrm{ZikV}$ is an arthropod-borne human pathogen first identified in 1947 in Uganda's rhesus monkeys. ${ }^{9}$ It is a positive sense, single stranded RNA virus of the family Flaviviridae, genus Flavivirus. ZikV has a 10,749-nt genome and is closely related to Spondweni virus. ${ }^{10}$ It was detected in humans in 1952 in Uganda and Tanzania. Subsequent outbreaks Zika Virus disease in Africa, America Asia and the Pacific has been reported. The virus has high potential for ongoing geographic expansion into countries where Aedes aegypti moquitoes are present. The primary transmission is through the bite of these specific species of mosquitoes that spread dengue and chikungunya viruses. ${ }^{11}$ Reports of non-vectorborne include possible Zika virus transmission during pregnancy or when mother is infected at the time of delivery and spread of the virus through blood transfusion and sexual contact. ${ }^{12}$ The most common symptoms of Zika virus disease are fever, rash, joint pain, and conjunctivitis. The illness is usually mild with symptoms lasting from several days to a week. Severe disease requiring hospitalization is uncommon. ${ }^{13}$ However ZikV infection could lead to GuillainBarré syndrome and pregnant women giving birth to babies with birth defects (microcephaly) and poor pregnancy outcomes based on previous investigations. ${ }^{14}$

Zika Virus is categorized as a Risk Group 2 pathogen and is not a select agent both for Centers for Disease Control and United States Department of Agriculture. The infectious dose is unknown and there has been no documented report of direct transmission of the virus in hospital or laboratory setting handling patients and clinical specimen infected with the virus. The virus is susceptible to autoclave temperature of $121^{\circ} \mathrm{C}, 1 \%$ bleach, $70 \%$ ethanol, and $2 \%$ gluteraldehyde organic solvent detergents. No vaccine is available and treatment is supportive.

\section{Identification of the Procedure Hazards}

Clinical specimens received at the Clinical Laboratory shall be transported to the Virology Annex-1 Laboratory, where aliquots of $200 \mu \mathrm{L}$ shall be obtained for PCR testing and for posible serology by ELISA. Testing shall be performed at the Virology Annex-2 laboratory and samples that are positive shall be stored at the Institution's Biobank facility. The activities and potential modes of exposure specific to the procedure to be conducted are summarized in Table 1.

Table 1. Activities and potential modes of exposure specific to the procedure to be conducted

\begin{tabular}{|c|c|}
\hline Activity & Exposure \\
\hline Donning Doffing PPE & $\begin{array}{l}\text { Direct contact with contaminated / } \\
\text { reused PPE }\end{array}$ \\
\hline $\begin{array}{l}\text { Specimen Reception / Opening of } \\
\text { Transport Boxes to check identity } \\
\text { and appropriateness of } \\
\text { samples submitted }\end{array}$ & $\begin{array}{l}\text { Direct contact with Clinical } \\
\text { Specimen due to broken primary } \\
\text { container, improperly sealed } \\
\text { containers, leaking container or } \\
\text { contaminated container }\end{array}$ \\
\hline $\begin{array}{l}\text { Reception of specimen } \\
\text { and Transport Boxes from } \\
\text { Clinical Laboratory }\end{array}$ & $\begin{array}{l}\text { Possible contact exposure from } \\
\text { contaminated material (request } \\
\text { form, pens, door knobs and } \\
\text { transport boxes) }\end{array}$ \\
\hline $\begin{array}{l}\text { Transport of specimen from Clinical } \\
\text { Laboratory to Virology Laboratory }\end{array}$ & $\begin{array}{l}\text { Possible contact exposure from } \\
\text { contaminated material (request and } \\
\text { transport boxes) }\end{array}$ \\
\hline $\begin{array}{l}\text { Encoding of patient information, } \\
\text { work sheets, logbooks and printing } \\
\text { of specimen labels (barcode) }\end{array}$ & $\begin{array}{l}\text { Possible contact exposure from } \\
\text { contaminated material (request) }\end{array}$ \\
\hline $\begin{array}{l}\text { Re-opening of transport boxes to } \\
\text { check identity and appropriateness } \\
\text { of samples submitted }\end{array}$ & $\begin{array}{l}\text { Direct contact with clinical specimen } \\
\text { including respiratory samples }\end{array}$ \\
\hline $\begin{array}{l}\text { Sorting of specimen according to } \\
\text { pre assigned specimen ID }\end{array}$ & $\begin{array}{l}\text { Direct contact with clinical } \\
\text { Specimen from the primary and } \\
\text { secondary container }\end{array}$ \\
\hline \multirow{2}{*}{ Centrifugation of blood specimen } & $\begin{array}{l}\text { Possible direct contact with blood } \\
\text { and blood-borne pathogens }\end{array}$ \\
\hline & $\begin{array}{l}\text { Spills and splashes in processing } \\
\text { infectious materials }\end{array}$ \\
\hline \multirow{2}{*}{$\begin{array}{l}\text { Opening of primary container } \\
\text { and obtaining aliquot sample by } \\
\text { pipetting for testing and storage }\end{array}$} & $\begin{array}{l}\text { Direct contact with clinical } \\
\text { specimen from the lid and caps of } \\
\text { primary containers }\end{array}$ \\
\hline & $\begin{array}{l}\text { Accidental spills and splashes in } \\
\text { processing infectious materials }\end{array}$ \\
\hline \multirow{2}{*}{$\begin{array}{l}\text { Transport of specimen to } \\
\text { Annex Laboratory }\end{array}$} & $\begin{array}{l}\text { Possible contact exposure from } \\
\text { contaminated material (request and } \\
\text { transport boxes) }\end{array}$ \\
\hline & $\begin{array}{l}\text { Possible tripping due to small and } \\
\text { obstructed space }\end{array}$ \\
\hline $\begin{array}{l}\text { Homogenization, vortex mixing } \\
\text { and pipetting and centrifugation of } \\
\text { serum for RNA Extraction and ELISA }\end{array}$ & $\begin{array}{l}\text { Spills and splashes in processing } \\
\text { infectious materials }\end{array}$ \\
\hline $\begin{array}{l}\text { Shipping fresh and inactivated } \\
\text { specimen for Reference laboratory } \\
\text { confirmation (WHO-Hong Kong) }\end{array}$ & $\begin{array}{l}\text { Possible contact exposure from } \\
\text { contaminated material (primary } \\
\text { and/or secondary container) }\end{array}$ \\
\hline
\end{tabular}




\section{Compliance of the RITM Virology Laboratory with} BSL-2 standards

The WHO recommends a minimum of Biosafety Level 2 for practices, containment, equipment and facility for handling infectious or potentially infectious material for Zika virus diagnosis. We have determined RITM Virology laboratory's compliance using the WHO Biosafety checklist. The findings are summarized in Figure 1.

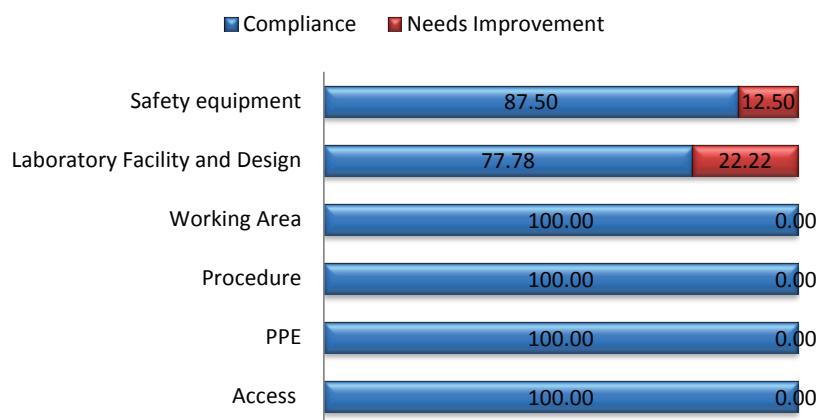

Figure 1. Compliance with WHO biosafety guidelines for basic laboratory (BLS1 and BLS2).

\section{Competence of Laboratory Personnel}

The protection of laboratory workers, other personnel working within and outside the laboratory, the general public and the environment will depend ultimately on competence, compliance and commitment of laboratory workers to biological safety. We have determined the proficiency of laboratory personnel who will be tasked to work with $\mathrm{ZikV}$.

A record of staff's name, age, gender, birth date, civil status, educational background and trainings related to biological safety, infectious substance shipping and technical skills in handling and laboratory diagnosis of infectious diseases was obtained.

Twenty-two (22) Virology Department personnel will be involved in specimen reception and processing, RNA extraction and testing, and results validation and reporting. Six personnel will be first line responders while the remaining personnel are reserved to respond as part of surge capacity plan. $73 \%$ are females, and $26 \%$ are males. The age ranges from 20 to 55 years. Majority are licensed Medical Technologists by profession and are civil service eligible. Staff had undergone local training on Biosafety and infectious substance shipping (Figure 2). Those who have been trained were certified shippers of infectious substances. Laboratory personnel are technically competent in laboratory diagnosis of human sample by PCR and ELISA. Those involved in the molecular testing are certified proficient in the performance of Polymerase Chain Reaction (PCR).

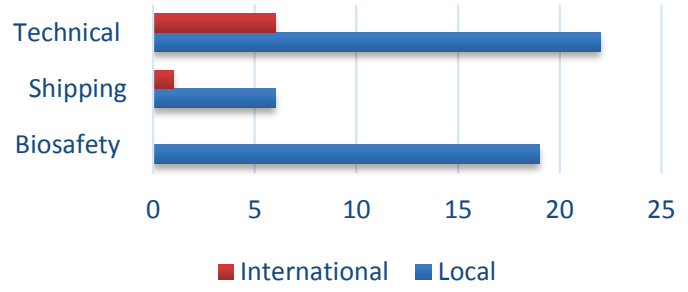

Figure 2. Trainings of laboratory personnel.

\section{Risk Characterization}

The risk of infection with ZikV ranges from very low to low (Figure 3), while the risk of infection with other blood-borne pathogens is found to be higher (Figure 4).

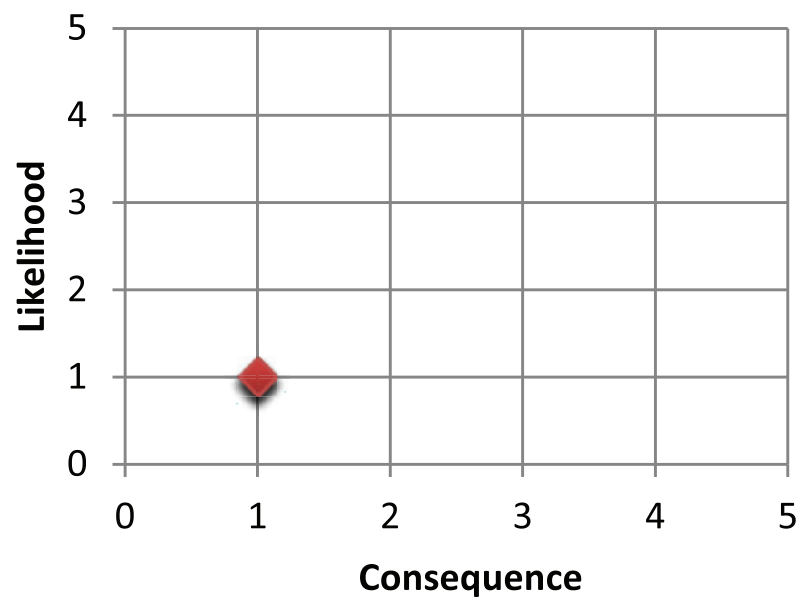

Figure 3. Risk matrix for acquiring zika infection.

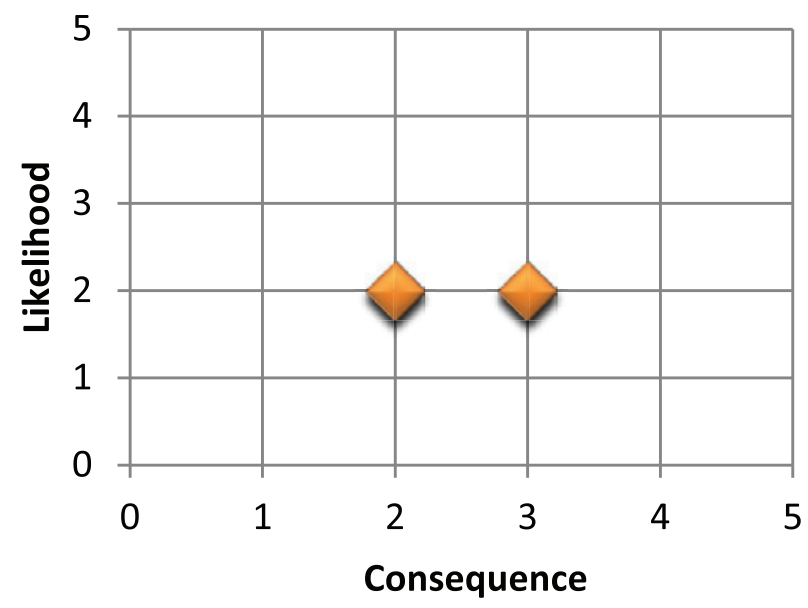

Figure 4. Risk matrix for acquiring other blood-borne pathogens infection processing human blood samples.

\section{BioRAMC Model}

The BioRAM@ $\odot$ Model has been utilized to identify biosafety risk of ZikV exposure to individuals in RITM Virology Laboratory, to the community and animals in the community while performing laboratory-based investigation and surveillance. BioRAM $\odot$ reported very low biosafety risk (Figure 5).

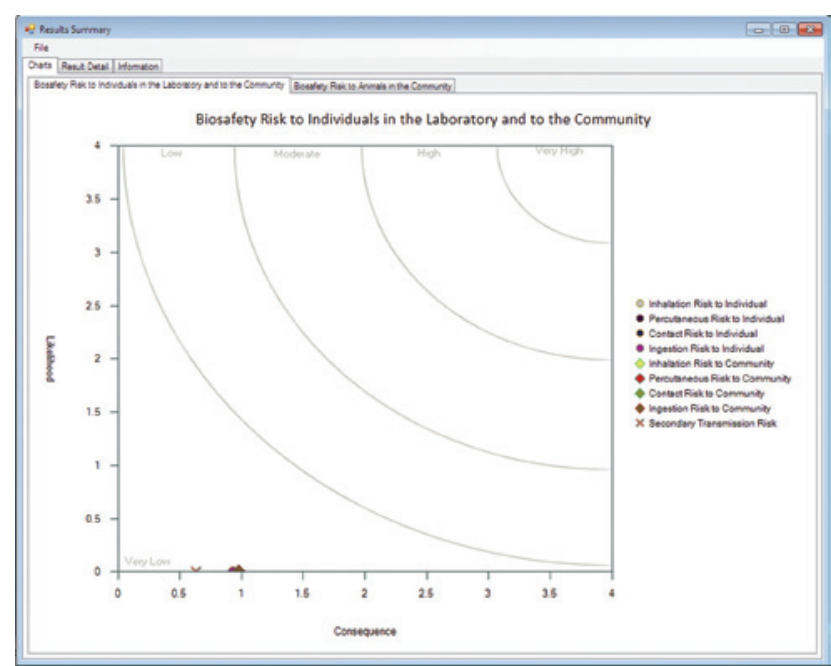

Figure 5. BioRAM@ result for Zika. 


\section{DISCUSSION}

The initial assessment of the risk has been performed by identifying the hazard of the agent and the procedure. We have determined the hazard of the agent by its capacity to infect and cause disease in a susceptible human host, its host range, the severity of disease it causes, the infectious dose, its stability in the environment, the mode of transmission and the availability of preventive measures and effective treatments. Compiled reports of laboratory acquired infections could also be a strong basis of the initial assessments, however, no reports have been documented specific for Zika infection in the laboratory. Due to the limited information about $\mathrm{ZikV}$, we relied on references found in the Internet to gather information. After reviewing all related and available information that supports the identification of the agent's hazard, the hazards of the laboratory procedures were identified.

The risk of LAI with ZikV as characterized in this risk assessment is low. Factors that have influenced low likelihood and consequence of $\mathrm{ZikV}$ infection includes the transmission requirement for an arthropod vector, the procedure to be conducted that has minimal potential exposure risk and the absence of reported LAI related TI ZikV. The reproductive cycle of ZikV follows that of other known flaviviruses like Dengue and Chikungunya. ZikV requires mosquito vectors from the genus Aedes. Transmission occurs when an infected vector feeds on a host with an incubation time of around 10 days.

We have enumerated all laboratory procedures related to ZikV diagnosis at the RITM. The principal probable exposure hazard that we have identified is through direct contact. The procedures also do not require the use of sharps, live animals and insect vectors for inoculation and culture, thus minimized the personnel's exposure to the virus. Possible use of sharps, during blood collection was considered. Caution must be observed as percutaneous transmission via blood transfusion is being investigated. Currently, there have been no reports of transmission via direct contact with contaminated material. While the exposure risk to $\mathrm{ZikV}$ virus is low in the laboratory setting, the risk of exposure to other bloodborne pathogens was found to be higher than the pathogen being assessed. Since human blood and serum are the optimum specimen for diagnosis, the risk of exposure to other blood-borne pathogens must be considered. To manage worst case consequences of exposure to these pathogens, a separate risk assessment should be conducted for each suspected pathogen.

The WHO recommends a minimum of Biosafety Level-2 practices, containment, equipment, containment and facility for handling $\mathrm{ZikV}$. In this risk assessment, we found that the laboratory is compliant to the requirements with the following recommendations. However, the Virology laboratory must work on its administrative controls and further improve the facility. Improper placement of supplies and equipment along the corridors and aisles are physical hazards. Accidental tripping due to obstructed walkways could lead to physical injury or potential exposure to infectious material if accidents occur during specimen manipulation. Windows must be fitted with arthropod screens that could be opened in case of emergencies. It also must develop its procedure for decontaminating equipment prior to repair and maintenance.

Since this risk assessment is only limited to the RITM Virology Laboratory, it is recommended that biological risk assessment be conducted in other laboratories included in the response (Clinical
Laboratory and Entomology laboratory). The Clinical Laboratory serves as the central specimen reception facility in charge of specimen collection within RITM, while Entomology Laboratory are involved in vector studies.

Risk assessment is fundamental in biological risk management program. The biological risk management program includes risk assessment, mitigation and monitoring the performance. Rapid risk assessment should be done as often as the introduction of new pathogen, technique, equipment, personnel, facility, procedure, practices, and/or mitigation control measure that may influence biological safety in laboratory. If done correctly, risk assessment, could provide effective allocation of resources to mitigate risk, identify training needs and supervision, evaluate procedural changes and exchange of work flow with other laboratories, and comply with standards and regulations.

Risk assessment must be documented. Risk must be communicated to all at stake personnel. Compliance with biosafety standards must be verified at least annually or as often as need arises. Initial risk assessment result must be reviewed prior conducting follow up risk assessment and when monitoring implemention of mitigation control measures.

Biosafety officers should lead in conducting the risk assessment. Technical staff, laboratory supervisor and subject matter experts must be involved as the quality of risk assessment result is dependent upon the exchange of ideas and findings. The laboratory head and biosafety officer are responsible for the implementation of biosafety recommendations and mitigation controls based on risk assessment. The institute is in charge of the biosafety administrative controls. Safe laboratory working environment, biological safety and the general welfare of all employees and researchers involved in Zika Virus activities and laboratory surveillance must be ensured.

\section{CONCLUSION}

Zika virus is an emerging public health threat. Laboratory diagnosis and surveillance of Zika is a critical component of response. However, biosafety is indispensable and must be considered. The process of doing the risk assessment is a vital strategy to ensure biological safety of laboratory personnel involved. We have analyzed and assessed the risk of acquiring Zika in RITM Virology laboratory as part of the overall preparedness. In this process we have documented that, the risk of acquiring $\mathrm{ZikV}$ infection while performing diagnositic test ranges from very low to low. The specimen to be collected and handled for $\mathrm{ZikV}$ diagnosis is human serum sample. The risk of acquiring other blood-borne pathogens is higher compared to the risk of infection to the pathogen being assessed. Mitigation control measures against direct contact and percutaneous exposure must be implemented and monitored. The laboratory is generally compliant with WHO basic laboratory biosafety standards required for ZikV laboratory diagnosis. Its staff are technically proficient for the procedure and are trained in biosafety. RITM is employing a documented risk assessment strategy as part of its biological risk management program. This risk assessment strategy will further strengthen laboratory capacity to respond to infectious disease threats and increase staff confidence in dealing with infectious materials in the laboratory.

\section{AUTHOR DISCLOSURE}

The authors declared no conflicts of interest. 


\section{ACKNOWLEDGEMENT}

The authors thank Ms. Ava Kristy Sy, the technical supervisor of the National Reference Laboratory for Dengue and other Arboviruses, and staff for their useful contribution to this document; Dr Robert Heckert, our mentor, for inspiring us to be biosafe all the time; and the 3rd batch of the Philippine Advanced Biorisk Officers Training Program (PhABOT3.0) for the shared passion and advocacy for biorisk management in the Philippines.

\section{REFERENCES}

1. Sikka V, Chattu VK, Popli RK, et al. The emergence of zika virus as a global health security threat: a review and a consensus statement of the INDUSEM Joint working Group (JWG). J Glob Infect Dis. 2016;8(1):3-15. http://dx.doi. org/10.4103/0974-777X.176140.

2. Duffy MR, Chen TH, Hancock WT, et al. Zika virus outbreak on Yap Island, Federated States of Micronesia. N Engl J Med 2009;360(24):2536-43. http://dx.doi.org/10.1056/ NEJMoa0805715. PMID: 19516034.

3. Musso D, Nhan T, Robin E, et al. Potential for zika virus transmission through blood transfusion demonstrated during an outbreak in French Polynesia, November 2013 to February 2014. Euro Surveill. 2014.19(15):1-3. http://dx.doi. org/10.2807/1560-7917.ES2014.19.14.20761.

4. Pessôa R, Patriota JV, de Souza L, et al. Investigation into an outbreak of dengue-like illness in Pernambuco, Brazil, revealed a cocirculation of zika, chikungunya, and dengue virus type 1. Medicine (Baltimore). 2016;95(12):e3201. http://dx.doi. org/10.1097/MD.0000000000003201. PMID: 27015222.

5. Grenoble R, Almendrala A, Schumaker E. WHO declares public health emergency around zika virus. 2016. (News). Retrieved from http://www.huffingtonpost. com/entry/world-health-org-zika-virus-emergency us_56af781ae4b077d4fe8ec2ac. Accessed March 28, 2015.
6. Alera MT, Hermann L, Tac-An IA et al. Zika virus infection, Philippines, 2012. Emerg Infect Dis. 2015;21(4): 722-4. http://dx.doi.org/10.3201/eid2104.141707.

7. Montano I. DOH confirms American woman tested positive for zika while in PH (News). http://cnnphilippines.com/ news/2016/03/06/doh-american-woman-positive-zika-ph.html. Accessed March 28, 2015.

8. Chosewood LC, Wilson DE. Biosafety in microbiological and biomedical laboratories, 5th Ed., 2009. http://www.cdc. gov/biosafety/publications/bmbl5/bmbl.pdf.

9. Dick GW, Kitchen SF, Haddow AJ. Zika virus (I). Isolations and serological specificity. Trans R Soc Trop Med Hyg. 1952;46(5):509-20. http://dx.doi.org/10.1016/0035-9203(52) 90042-4.

10. Lanciotti RS, Kosoy OL, Laven JJ, et al. Genetic and serologic properties of Zika virus associated with an epidemic, Yap State, Micronesia, 2007. Emerg Infect Dis 2008;14(8):12321239 .

11. Hayes EB. Zika virus outside Africa. Emerg Infect Dis. 2009; 15(9)1347-50. http://dx.doi.org/10.3201/eid1509.090442.

12. Foy BD, Kobylinski KC, Chilson Foy JL, et al. Probable non-vector-borne transmission of Zika virus, Colorado, USA. Emerg Infect Dis. 2011;17(5):880-8. http://dx.doi. org/10.3201/eid1705.101939.

13. Armstrong H, Hennessey M, Adams M, et al. Travelassociated zika virus disease cases among U.S. Residents - United States, January 2015-February 2016. Morb Mortal Wkly Rep. 2016;65(11):286-9.

14. Oehler E, Watrin L, Larre $\mathrm{P}$, et al. Zika virus infection complicated by Guillain-Barre syndrome - case report, French Polynesia, December 2013. Euro Surveill. 2014;19(9). http://dx.doi.org/10.2807/1560-7917.ES2014.19.9.20720.

Disclaimer: This journal is OPEN ACCESS, providing immediate access to its content on the principle that making research freely available to the public supports a greater global exchange of knowledge. As a requirement for submission to the PJP, all authors have accomplished an AUTHOR FORM, which declares that the ICMJE criteria for authorship have been met by each author listed, that the article represents original material, has not been published, accepted for publication in other journals, or concurrently submitted to other journals, and that all funding and conflicts of interest have been declared. Consent forms have been secured for the publication of information about patients or cases; otherwise, authors have declared that all means have been exhausted for securing consent. 